\title{
Electoral Reform: What Do Political Scientists Know that Practitioners Do Not? Lessons from the UK Referendum of 2011
}

\author{
Alan Renwick, Constitution Unit, Department of Political Science, University College London
}

Typescript of article published in Election Law Journal

Note: This version does not include final corrections. Please cite the published version.

\begin{abstract}
Political scientists might hope to offer practitioners involved in debates about electoral reform insights regarding either the process of reform or its potential effects. In respect of each of these, the practitioners whom we engage might by either elite decision-makers or the activists, journalists, and regular citizens who constitute the bedrock of democracy. The UK's electoral reform referendum of 2011 offers a good opportunity to explore the degree to which political scientists in fact offer original insights in these various areas. The paper argues that, despite the great efforts that political scientists have expended in refining ever more sophisticated models of electoral system effects, elite practitioners have often - though not always - got there before us. By contrast, at least in the UK, practitioners sometimes fall short of political scientists in their understanding of how reform processes might unfold, and there is also a clear and strong need for political scientists to assist in educating public opinion. These findings have implications for how we should think about political science research: the research that practitioners most value is often not the research that has the highest prestige within the discipline.
\end{abstract}

Keywords: alternative vote; electoral reform; political science; referendum; research impact; United Kingdom 
The question asked by the editors of this symposium is both important and intriguing. It is important because political scientists need to attend to the issue of how our research adds usefully to the sum of human knowledge. Practitioners sometimes suspect us of work that is overly abstract or theoretical and that therefore fails to deliver fresh knowledge with clear practical implications. Some practitioners, critical of political science's value, have even sought to impede that work, as when, in 2013, National Science Foundation funding for political science research in the United States was severely restricted. Clarifying the utility of our work therefore matters. Yet the question is also intriguing because it is not immediately obvious what our answer should be: in the realm of electoral systems, savvy practitioners often know just as much as we do.

I shall explore these issues through the example of the UK's referendum in May 2011 on whether to change the electoral system from the traditional first past the post (FPTP) system to the alternative vote (AV). I participated in the referendum campaign as an impartial expert: I wrote a book - A Citizen's Guide to Electoral Reform - which set out the issues raised by the referendum for the lay reader; subsequently, I also authored a briefing paper on the subject for the UK Political Studies Association, which was downloaded over 22,000 times during the campaign and used widely by journalists and others. I shall comment on what, in my perception, these interventions contributed. In order to avoid the danger of selection bias, I shall look at other stages in the referendum process as well, and I shall supplement my reflections on the 2011 referendum with analysis of electoral reform debates in the UK more widely.

I will argue that our endeavours can add original knowledge, but not always in the ways that have highest prestige within political science. I will suggest that this has implications for what our own priorities should be.

\section{The Case: The UK Electoral Reform Referendum of 2011}

Voters across the UK went to the polls on 5 May 2011 to answer the following question:

At present, the UK uses the "first past the post" system to elect MPs to the House of Commons. Should the "alternative vote" system be used instead? (Electoral Commission 2011: 4)

The vote thus pitted first past the post (FPTP) - the electoral system that has been used to fill all seats in the UK House of Commons since 1950 (and the vast majority of seats for much longer) - against another majoritarian electoral system using single-member districts: the alternative vote (AV) system, also known as preferential voting (PV) or instant runoff voting (IRV).

The referendum was called immediately after the general election of 2010. By way of context, Table 1 shows the results of that election in terms of both seats and votes, showing the extent to which each party gained or lost from the electoral system's disproportionality.

[Table 1 about here]

During the campaign preceding the 2010 election, the Labour Party had advocated a referendum on introducing AV (Labour Party 2010: 9:3), while the Conservatives supported the status quo (Conservative Party 2010: 67), and the smaller Liberal Democrats campaigned for the introduction of proportional representation (PR) (Liberal Democrats 2010: 87-8). The election gave no party an overall 
majority, and subsequent negotiations led to a coalition government comprising the Conservatives and Liberal Democrats. Yet it was Labour's policy - a referendum on AV - that the coalition agreement endorsed. This was a compromise: the Liberal Democrats were adamant on securing progress towards electoral reform; a referendum on AV was the most the Conservatives would accept.

Early polls suggested widespread public sympathy for the idea of electoral reform (Qvortrup 2012: 114). But AV's initial lead subsequently declined. In the end, with turnout of 42.2 per cent, 32.1 per cent of voters supported change, while 67.9 per cent voted to retain the status quo (Electoral Commission 2011: 4-5). Thus, the idea of electoral reform was thrown decisively off the political agenda.

Research by political scientists might have contributed to this reform debate in either of two ways: by delivering insights into the process of electoral reform; or by informing understandings of the putative reform's likely effects. We can also subdivide possible contributions by their audience: whether the politicians and others at the heart of the elite-level decision-making processes relating to the referendum; or the activists, journalists, and regular citizens who took part in the public campaign and the popular vote.

My own contribution related to the second element on each of these dimensions: it concerned the likely effects of the proposed reform; and it was directed at journalists and members of the public. It comprised two primary elements. First, my book, A Citizen's Guide to Electoral Reform, introduced the choice between FPTP and AV as well as other electoral reform proposals that were foreshadowed in the Conservative-Liberal Democrat coalition agreement (Renwick 2011a). My decision to pitch this book to publishers in the weeks after the coalition agreement was signed reflected an expectation that referendum campaigners would advance exaggerated and often misleading arguments, and that a book setting out the issues, arguments, and evidence neutrally and dispassionately might aid the quality of the debate. The book was written over the summer of 2010 and published in January 2011, four months before the referendum.

Second, in March 2011, I produced a much shorter (10,000-word) briefing paper focusing specifically on the choice between FPTP and AV (Renwick 2011b). This was commissioned and published by the UK Political Studies Association and was intended to summarize the research evidence on key issues of debate in the referendum campaign. That campaign began officially on 16 February 2011, and so the main terms of debate were already evident when the briefing paper was planned and written. The intended audience was, again, journalists and members of the public.

I shall set out to what extent and how these contributions added to the referendum discussion in the following section. As I indicated above, however, my interventions occurred in only one of several areas in which political science knowledge might have been valuable. The referendum campaign came at the end of the attempted reform process. Before that, political actors needed to come to a view as to what electoral institutions they would prefer; and they had to decide whether they wanted a referendum on this question at this time to occur. Ignoring these earlier stages would risk selection bias in our attempt to gauge the contribution that political scientists can make: if we focus only on the stages where we, as experts, in fact contributed, we are likely to overestimate our value in the process as a whole. In what follows, I therefore examine the three stages just described. These correspond to three of the four areas of potential contribution by political scientists: understanding of the likely effects of different reforms among political elites; understanding of reform processes among political elites; and understanding of likely reform effects among non-elites. I do not consider non-elite understandings of the reform process, as the decision to hold the referendum was entirely an elite matter. 


\section{Contributing to the Reform Debate}

\section{Understanding of Reform Options among Political Elites}

I made no contribution to the development of understanding among political elites of the likely effects of different electoral reform options, nor to the parties' decisions as to their electoral system preferences. Nor, to my knowledge (at least, directly) did any other political scientist. This was because the parties already had understandings and established preferences.

The Liberal Democrats were (and remain) longstanding advocates of electoral reform: as the third party in British politics, they had suffered underrepresentation at every UK general election under FPTP since 1922. They knew that PR would translate votes into seats more accurately for smaller parties. They knew also that AV was not a proportional system. Nevertheless, they were aware that AV tends to benefit centrist parties that can pick up second and lower preferences, and they hoped that a move to AV might be a stepping stone towards deeper change.

The Conservatives, meanwhile, were equally longstanding defenders of FPTP. Having been in government for longer than any other party - they were the sole governing party for fifty-one years of the twentieth century and partnered in government for another sixteen - they have been the principal beneficiaries of FPTP's capacity (in the right circumstances) to manufacture single-party majorities in the legislature. Even following their crushing electoral defeats in 1997 and 2001, they preferred to play a long game of returning to majority power, and they knew that moving to PR would likely prevent that. They were worried that AV might allow the centre-left parties to coalesce more effectively against them, but they were willing to countenance a referendum, at least in part, because they saw that the effect would be limited.

Labour has for some years been the party containing most diversity of opinion on electoral systems. Some prominent figures support PR, either on fairness grounds or because they see it as a mechanism through which a natural centre-left majority could prevent the election of Conservative governments. In 1997, following four successive election defeats, their manifesto pledged an inquiry, followed by a referendum, on PR (Labour Party 1997: 33). The party leadership have, however, consistently favoured majoritarian politics, and the promised referendum never materialized. Nevertheless, in 2009, responding to public anger over a scandal concerning MPs' expense claims, Prime Minister Gordon Brown pledged that his party would call a referendum on AV after the 2010 election if it was reelected. The idea was to offer something that would at least appear to respond to a popular desire for greater accountability of MPs to their constituents while having little impact on Labour's power interests.

What is notable about each of these brief descriptions of the main parties' thinking on electoral systems is that they all understood those systems' likely effects on the distribution of power. The practitioners already knew what political scientists know in this regard.

Before drawing the conclusion that political scientists have little useful to add, we can ask three questions. First, was there nothing about the likely effects of a shift to AV that political scientists knew but practitioners did not? Second, where practitioners understood electoral system effects, was this in fact only because they had already learnt from political scientists, such that the scholars' role in the overall process remains important? Third, was this an unusual case of practitioner perspicacity, or does such understanding reflect a general pattern? 
Regarding the first question, there is at least one general effect of electoral systems that political science research suggests practitioners often get wrong: at least in the UK, many politicians and journalists take it as self-evident that single-party-majority government is associated with effective government, especially effective economic management, whereas coalition or minority governments are linked to instability, indecision, and drift. Opponents of PR often cast Italy - rather than, say, Germany or the Netherlands - as the archetype of proportional politics. Even supporters can be apologetic on this point. Yet studies by political scientists and economists suggest that any economic effects of the electoral system are relatively small and that more proportional systems may, if anything, encourage faster economic growth (e.g., Persson and Tabellini 2005; Knutsen 2011).

We can get closer to answering the second and third questions by looking deeper into the history of electoral reform debates in the UK beyond the AV referendum. Despite the UK's electoral system stability, multiple opportunities to observe practitioners' knowledge and understanding of electoral systems exist: reform of the Westminster system has been discussed for decades; away from Westminster, various systems have been introduced in recent years; in earlier decades, UK practitioners imposed or promoted particular electoral rules in numerous countries worldwide.

We can take the best-known findings of political science as our starting point. According to Duverger's laws (or Duverger's Law and Hypothesis), plurality systems constrain the number of parties, while proportional systems permit (though they do not entail) a greater number of parties. Riker (1982) characterized these observations over thirty years ago as among the most notable examples of political science working well, and considerable attention has continued to be lavished upon them since (e.g., Amorim Neto and Cox 1997; Clark and Golder 2006). The difficulty for political scientists wishing to proclaim our value to the world is, however, that practitioners in the UK (as elsewhere) already knew these patterns before Duverger ever wrote them down and before political scientists conducted any sophisticated studies. Colomer's rule - that large parties prefer majoritarian electoral systems while small parties prefer proportional systems (Colomer 2005: 2) - has characterized debates regarding the Westminster electoral system since at least the 1920s: that is why the parties have held the electoral system preferences briefly sketched above (for more detail, see Hart 1992; Butler 1963).

The other principal aspect of an electoral system besides proportionality is personalization - the intraparty dimension as opposed to the inter-party dimension. Political scientists until recently left this dimension largely unexplored (see, e.g., Colomer 2011; Renwick and Pilet 2016). But here too, the practitioners have long been ahead of us. If we look, for example, at debates over the electoral system for the Maltese legislature in 1920 and 1921, the British authorities advocated STV in preference to the list system supported by the Maltese parties on the basis that it would give voters more choice and more influence over who was elected and weaken the power of political parties. The Maltese political elite displayed equal understanding, which, combined with their different interests, led them to the opposite conclusions (Renwick and Pilet 2016: 83-4).

In respect, therefore, of many of the key relationships between electoral systems and outcomes, for the elucidation of which much scholarly sweat has been shed, we have often done no more than confirm what practitioners already knew. That is not to say that political scientists have had no role in wider electoral reform debates in the UK. Contributions have been important, for example, in cases where innovative electoral rules have been devised, such as the supplementary vote system now used for mayoral elections (Dunleavy and Margetts 1998) and the AV+ system proposed by the 1998 Jenkins Commission (Independent Commission on the Voting System 1998). Political scientists have also provided detailed modelling of electoral system effects (e.g., Curtice and Steed 1982: 285-6; Sanders et al. 2011) and calculations of different forms of electoral system bias (Johnston, Rossiter, and Pattie 2006). With regard to the big picture, however, we have good reason to show some humility. 


\section{Understanding of Reform Processes among Political Elites}

Political scientists were absent also from practitioners' assessments of how the process of electoral reform itself might go. The proposal for a referendum on AV was hatched very rapidly in the days following the 2010 election in closed-door coalition negotiations among key representatives of the parties (Kavanagh and Cowley 2010: 225-6). Calculations of what the result of the referendum might be were limited to hunch rather than detailed analysis.

In this case, it is not so clear that the practitioners knew all that political scientists could have told them. The Conservatives' willingness to allow the referendum may have been based not just on the perception that adoption of AV would be a change they could live with, but also on the expectation that the bid for reform might well fail - an expectation that proved well-grounded. But the Liberal Democrats badly miscalculated: by losing the referendum so handsomely, they did their own reputation and the cause of electoral reform considerable damage.

The question is whether the Liberal Democrats could have averted this miscalculation had they listened to political scientists at the time of the coalition negotiations. It is not unreasonable to say that they could. Political scientists have for years pointed out that major electoral reforms in established democracies are rare events (e.g., Nohlen 1984): reform attempts are much more likely to fail than to succeed. Referendum scholars, meanwhile, have pointed out that an early poll lead is far from guaranteeing success in the final vote (LeDuc 2002). In my own work, I have suggested there are two basic routes to reform: top-down elite majority imposition, when the politicians in power enact reform that they think will serve their interests; and bottom-up elite-mass interaction, when public anger over the status quo forces reluctant politicians to accept change (Renwick 2010). The Liberal Democrats' reform attempt in 2010-11 fitted neither pattern. They sought reform by elitemass interaction. But public anger with the state of politics, though raised by the 2009 expenses scandal, was subsiding. More importantly, there was no convincing story as to why AV would help sort things out (Renwick, Lamb, and Numan 2011: 40). When voters do not see the point of a change that is offered to them, they tend to stick to the security of the status quo.

Here, therefore, political scientists did know more about the dynamics of electoral reform and public opinion than at least some of the practitioners, and those practitioners suffered by their failure to listen.

\section{Understanding of Reform Options in the Wider Public}

Finally, I turn to the stage of the attempted reform process in which I did play a role: the referendum campaign itself. Few political scientists came out openly for one side or the other during the campaign. My role was that of an impartial expert, offering evidence and analysis without taking sides. My focus was on the practitioners of democracy broadly understood: not the politicians, but the journalists and ordinary members of the public. Among these groups, ignorance of the options available in the referendum was deep. As Vowles (2013) shows, many voters had profound misunderstandings of the options available to them in the referendum: more, for example, believed than disbelieved the statement that "AV means that some votes get counted more than others" (Vowles 2013: 221). Earlier research had also found common misunderstandings even of FPTP, despite its longstanding use: Farrell and Gallagher (1999: 300), using focus groups, found that many voters did not realize that a candidate could be elected under FPTP without securing an absolute majority of the vote. 
Such ignorance was fed (often consciously) in the weeks and months before the referendum by the main campaign groups, which propounded numerous manifest falsehoods (Renwick and Lamb 2013). These falsehoods were most unabashed in the anti-AV campaign, which asserted that AV would violate the principle of "one person, one vote" and that its introduction would cost a sum that at least one leading anti-AV campaigner acknowledged was simply made up (Shackle 2011). But the pro-AV campaign also made false claims - for example, about the degree to which MPs were "shirking" and about how far AV might change this.

Among at least some journalists, there was an appetite for the impartial expert information about the referendum options that the PSA briefing paper provided. That paper was referred to as a source in articles in the Guardian, Independent, Times, and Sunday Express newspapers, and by the FullFact and Channel 4 fact-checking websites. It led to my authoring articles for the Guardian, the Times, and the BBC News website, as well as to numerous broadcast appearances. On the other hand, this was a relatively low-key referendum campaign: the levels of media coverage and of turnout were far below those seen five years later in the referendum on the UK's membership of the European Union. The degree to which any effort emerged to debunk myths was limited.

The extent of wider public interest in such factual information is hard to judge. Whatever its level, however, another issue also deserves attention: namely, that it should not be supposed that political scientists have a monopoly of wisdom over even citizen practitioners. My book and briefing paper both set out a range of criteria that might be used to judge among competing electoral systems and then analysed the evidence as to how each system measured up against these criteria. The briefing paper, for example, used six criteria that were drawn from the debate as it existed at the time:

1. $A V$ and the voter: does $A V$ help voters to express themselves at the ballot box?

2. $A V$ and the result of the election at constituency level: does AV guarantee majority support for the MP elected and does it produce fair constituency results?

3. $A \bigvee$ and the result of the election at national level: how would $A V$ change the balance between the parties and what impact would this have on the quality of government in the UK?

4. AV and the character of politics: would $A V$ change the nature of political discourse or the behaviour of MPs?

5. the cost of AV: how much independent evidence is there on how much AV would actually cost to operate?

6. $A V$ and the future of the electoral system: would the adoption of $A \bigvee$ make further changes to the electoral system thereafter more or less likely? (Renwick 2011b: 3)

Neither the book nor the briefing paper offered any judgement as to the weight that should be attached to these criteria: that is a matter on which there is legitimate value disagreement. In at least some cases, voters' weightings appeared to diverge from those that are often expected by political scientists. Notably, the academic literature tends to treat it as obvious that FPTP offers voters very little choice and that a preferential system such as AV would be more pleasing to citizens, in that it would allow them to express their preferences more fully. The AV referendum casts doubt upon that. The voter choice argument, though often made, had little traction, whereas the claim that FPTP gave voters the simple power to vote a candidate in or out held much more sway. This fits with comparative evidence. Political scientists tend to treat FPTP systems as offering little voter choice or personalization: indeed, this system is sometimes characterized as a closed-list system with a district magnitude of one (Carey and Shugart 1995: 425-6). Theoretically, this categorization makes perfect sense. But it seems voters do not perceive it that way: recent research into electoral system personalization in European democracies found no country using single-member districts - either to 
elect all deputies or, as under mixed-member systems, to elect a significant proportion of them - in which there was any significant debate around any need for greater electoral system personalization (Renwick and Pilet 2016: 213). Thus, it appears that we, as political scientists, are prone to overestimating the degree of engagement with politics and political choices that most voters want.

\section{What Political Scientists Can Add to Electoral Reform Debates}

Three conclusions arise from these observations. First, political scientists (and other scholars) have a clear and important role to play in conveying understanding of electoral systems and their effects - as well as other building blocks of the political system - to broad publics. The political ructions of 2016 have brought widespread talk of "post-truth politics" and scepticism towards the value of expert interventions in policy debates. But the work of political scientists has yielded important findings about how different electoral system options might contribute towards or detract from the various ends that people might wish to pursue. Even where practitioners know the same as we know, that we are able to offer rigorous, impartial evidence is important. Voters still trust and want to hear from academics much more than they do politicians or journalists (Ipsos MORI 2016a, 2016b).

Second, while we do know some things about electoral reform processes and electoral system effects that elite practitioners do not know, much political science research has only confirmed patterns that practitioners were already aware of. Furthermore, even our original insights are often not really listened to. This suggests a need to reflect further on what we research and how we communicate our findings to non-academics. Careful analysis of the evidence regarding patterns that we and others think we already understand is, of course, important, for unrigorous perceptions can be either wrong or insufficiently nuanced. In addition, however, practitioners often want not ever more sophisticated demonstrations of general patterns that they (feel they) already understand, but, rather, something more specific: either technical understanding of electoral system details; or contextual understanding of how the general patterns are likely to play out in a particular case. Work of these kinds has relatively low status in contemporary political science. But we will need more of it if we wish to gain the ear of more practitioners.

Third, we should remember also that learning can go both ways: practitioners can usefully learn from academics; but academics can also learn from practitioners, be they elite politicians, journalists, activists, or ordinary members of the public. In particular, while political scientists can be good at understanding the degree to which different options are likely to promote possible purposes, it is not for political scientists to dictate what those purposes should be. Most of us would, I suspect, agree with that and find it obvious. Yet our research is often based upon assumptions about which purposes in fact matter to people - assumptions that we rarely attempt to test in any depth. The failure of academic research to notice and attend to the full range of people's real concerns has been a major topic of discussion in the wake of the Brexit referendum and the Trump election victory: this is a pattern that extends well beyond the study of electoral systems.

In short, political scientists have important contributions to make. But we should pursue them in dialogue with others so that we understand what practitioners need. If we simply pursue our own research agendas and seek to impart wisdom de haut en bas, we will in fact too often deliver findings that practitioners find either unoriginal or irrelevant. 


\section{Table}

Table 1. Results of the 2010 UK general election (Great Britain only)

\begin{tabular}{lccc}
\hline & Vote share (\%) & Seat share (\%) & Seat share - Vote share \\
\hline Conservatives & 37.0 & 48.6 & +11.6 \\
Labour & 29.7 & 40.8 & +11.1 \\
Liberal Democrats & 23.6 & 9.0 & -14.6 \\
UK Independence Party (UKIP) & 3.1 & 0 & -3.1 \\
Green Party & 1.0 & 0.2 & -0.8 \\
Scottish Nationalists (SNP) & 2.1 & 0.9 & -1.2 \\
Plaid Cymru & 0.7 & 0.5 & -0.2 \\
Others & 3.3 & 0.2 & -3.1 \\
\hline
\end{tabular}

Source: Cowley and Kavanagh (2010: 352-3). 


\section{References}

Amorim Neto, Octavio, and Gary W. Cox (1997). "Electoral Institutions, Cleavage Structures, and the Number of Parties". American Journal of Political Science 41, no. 1 (January), 149-74.

Butler, D. E. (1963). The Electoral System in Britain since 1918, 2nd ed. Oxford: Oxford University Press.

Carey, John M., and Matthew Soberg Shugart (1995). "Incentives to Cultivate a Personal Vote: A Rank Ordering of Electoral Formulas". Electoral Studies 14, no. 4 (December), 417-39.

Clark, William Roberts, and Matt Golder (2006). "Rehabilitating Duverger's Theory: Testing the Mechanical and Strategic Modifying Effects of Electoral Laws". Comparative Political Studies 39, no. 6 (August), 679-708.

Colomer, Josep M. (2005). “It's Parties that Choose Electoral Systems (or, Duverger's Laws Upside Down". Political Studies 53, no. 1 (March), 1-21.

Colomer, Josep M., ed. (2011). Personal Representation: The Neglected Dimension of Electoral Systems. Colchester: ECPR Press.

Conservative Party (2010). Invitation to Join the Government of Britain: The Conservative Party Manifesto 2010. London: Conservative Party.

Curtice, John, and Michael Steed (1982). "Electoral Choice and the Production of Government: The Changing Operation of the Electoral System in the United Kingdom since 1955". British Journal of Political Science 12, no. 3 (July), 249-98.

Dunleavy, Patrick, and Helen Margetts (1998). Report to the Government Office for London: Electoral the London Mayor and the London Assembly, 20 January. Available at http://eprints.Ise.ac.uk/28883/, accessed 16 December 2016.

Electoral Commission (2011). Referendum on the Voting System for UK Parliamentary Elections: Report on the May 2011 Referendum. London: Electoral Commission.

Farrell, David M., and Michael Gallagher (1999). "British Voters and Their Criteria for Evaluating Electoral Systems". British Journal of Politics and International Relations 1, no. 3 (October), 293-316.

Hart, Jenifer (1992). Proportional Representation: Critics of the British Electoral System, 1820-1945. Oxford: Clarendon.

Independent Commission on the Voting System (1998). Report of the Independent Commission on the Voting System (CM 4090-I). London: The Stationery Office.

Ipsos MORI (2016a). "Ipsos MORI Veracity Index 2015: Trust in Professions”, 22 January. Available at https://www.ipsos-mori.com/researchpublications/researcharchive/3685/Politicians-are-stilltrusted-less-than-estate-agents-journalists-and-bankers.aspx, accessed 16 December 2016.

Ipsos MORI (2016b). "Businesses and Brexit". Available at https://www.ipsosmori.com/Assets/Docs/Polls/ipsos-mori-business-and-brexit.pdf, accessed 16 December 2016.

Johnston, Ron, David Rossiter, and Charles Pattie (2006). "Disproportionality and Bias in the Results of the 2005 General Election in Great Britain: Evaluating the Electoral System's Impact". Journal of Elections, Public Opinion, and Parties 16, no. 1, 37-54. 
Kavanagh, Dennis, and Philip Cowley (2010). The British General Election of 2010. Basingstoke: Palgrave Macmillan.

Knutsen, Carl Henrik (2011). "Which Democracies Prosper? Electoral Rules, Form of Government and Economic Growth". Electoral Studies 30, no. 1 (March), 83-90.

Labour Party (1997). New Labour: Because Britain Deserves Better. London: Labour Party.

Labour Party (2010). The Labour Party Manifesto 2010: A Future Fair for All. London: Labour Party.

LeDuc, Lawrence (2002). “Referendums and Elections: How Do Campaigns Differ?” In David M. Farrell and Rüdiger Schmitt-Beck (eds), Do Political Campaigns Matter? Campaign Effects in Elections and Referendums. London: Routledge, pp 145-62.

Liberal Democrats (2010). Liberal Democrat Manifesto 2010. London: Liberal Democrats.

Nohlen, Dieter (1984). "Changes and Choices in Electoral Systems". In Arend Lijphart and Bernard Grofman (eds.), Choosing an Electoral System: Issues and Alternatives. Westport, CT: Praeger, 217-24.

Persson, Torsten, and Guido Tabellini (2005). The Economic Effects of Constitutions. Cambridge, MA: MIT Press.

Qvortrup, Matt (2012). "Voting on Electoral Reform: A Comparative Perspective on the Alternative Vote Referendum in the United Kingdom". Political Quarterly 83, no. 1 (January-March), 108-16.

Renwick, Alan (2011a). A Citizen's Guide to Electoral Reform. London: Biteback.

Renwick, Alan (2011b). The Alternative Vote: A Briefing Paper. London: Political Studies Association.

Renwick, Alan, and Michael Lamb (2013). "The Quality of Referendum Debate: The UK's Electoral System Referendum in the Print Media". Electoral Studies 32, no. 2 (June), 294-304.

Renwick, Alan, Michael Lamb, and Berna Numan (2011). "The Expenses Scandal and the Politics of Electoral Reform". Political Quarterly, 82, no. 1 (January-March), 32-41.

Renwick, Alan, and Jean-Benoit Pilet (2016). Faces on the Ballot: The Personalization of Electoral Systems in Europe. Oxford: Oxford University Press.

Riker, William H. (1982). "The Two-Party System and Duverger's Law: An Essay on the History of Political Science". American Political Science Review 76, no. 4 (December), 753-66.

Sanders, David, Harold D. Clarke, Marianne C. Stewart, and Paul Whiteley (2011). "Simulating the Effects of the Alternative Vote in the 2010 UK General Election". Parliamentary Affairs 64, no. 1 (January), 5-23.

Shackle, Samira (2011). "No campaign used made-up figures', says David Blunkett". New Statesman (online), 5 May. Available at http://www.newstatesman.com/blogs/the-staggers/2011/05/campaignfigure-blunkett, accessed 16 December 2016.

Vowles, Jack (2013). "Campaign Claims, Partisan Cues, and Media Effects in the 2011 British Electoral System Referendum". Electoral Studies 32, no. 2 (June), 253-64. 